[Case Report]

\title{
Infective Tricuspid Valve Endocarditis Due to Abscess of an Endogenous Arteriovenous Fistula in a Chronic Hemodialysis Patient
}

\author{
Noriko Hirakawa ${ }^{1}$, Hiromi TASAKI ${ }^{1}$, Seiya TANAKA ${ }^{1}$, Kazuhito Yamashita ${ }^{1}$, \\ Masahiro OKAZAKI ${ }^{1}$, Yasuhide NAKASHIMA ${ }^{1}$, Narutoshi KABASHIMA ${ }^{2}$ and \\ Masahito TAMURA ${ }^{2}$ \\ ${ }^{I}$ Second Department of Internal Medicine, School of Medicine, University of Occupational and Environ- \\ mental Health, Japan. Yahatanishi-ku, Kitakyushu 807-8555, Japan \\ ${ }^{2}$ Kidney Center, University Hospital, University of Occupational and Environmental Health, Japan. \\ Yahatanishi-ku, Kitakyushu 807-8555, Japan
}

Abstract: Patients on chronic hemodialysis are at high risk for endocarditis due to prosthetic access devices. Right-sided endocarditis without any predisposing factors is rare in dialysis patients. A 76-year-old female, who had chronic renal failure had been treated by hemodialysis and had a permanent pacemaker implanted, was admitted to our hospital with a high fever and lumbago after abscess formation at an autogenous arteriovenous fistula for hemodialysis. Methicillin Resistant Staphylococcus Aureus was identified by blood culture examination. Echocardiography revealed vegetation attached to the tricuspid valve. Chest X-ray and perfusion lung scintigraphy showed pulmonary infarction, perhaps due to vegetationderived emboli. Computed tomography also showed pyogenic spondylitis in L4 and L5. Repeated vascular punctures even of autogenous grafts expose dialysis patients to bacteremia and imply a higher risk of infectious endocarditis.

Key words: infective endocarditis, tricuspid valve, hemodialysis, permanent pacemaker.

(Received 13 August 2004, accepted 18 October 2004 )

\section{Introduction}

Patients receiving long-term hemodialysis are exposed to bacteremia due to frequent percutaneous needle punctures used to shunt or place indwelling venous catheters. Bacteremia,

\footnotetext{
Corresponding Author: Hiromi Tasaki, MD, PhD

Second Department of Internal Medicine, School of Medicine, University of Occupational and Environmental Health, 1-1 Iseigaoka, Yahatanishi-ku, Kitakyushu 807-8555, Japan.

Tel.: 81-93-691-7436, Fax: 81-93-691-6913,E-mail: h-tasaki@med.uoeh-u.ac.jp
} 
which logically would place patients at risk for the development of infective endocarditis, inevitably develops during some hemodialysis treatments at an estimated rate of 1 episode per 100 patient-care months [1]. Right-sided endocarditis usually occurs in intravenous drug abusers or intensive care patients with peripheral or central venous catheters, most often involving the tricuspid valve. However, right-sided endocarditis due to puncture of an endogenous arteriovenous fistula in a chronic hemodialysis patient is uncommon $[1-3]$. Infectious complications are also rare after pacemaker implantation. Here we report a hemodialysis case with endocarditis and discuss endocarditis in the right side of the heart with reference to the literature.

\section{Case report}

A 76-year-old female, who had chronic renal failure (CRF) that was treated by hemodialysis, was admitted to Nakama Municipal Hospital with high fever. Although she had been often diagnosed as suffering from renal failure since the age of 40 , she did not obtain treatment until she began hemodialysis at 71 years of age in 1998. Therefore, we could not diagnose the underlying disease for her CRF. Hemodialysis had been done through punctures at the artificial autogenous internal arteriovenous shunt, which was reconstructed twice in 1998 and in 1999 because of stenotic shunt. She also suffered from angina pectoris and underwent percutaneous transluminal coronary angioplasty (PTCA) with stenting to the left anterior descending artery in 1999, followed by PTCA again to correct restenosis in 2000. She had then been free from angina for 2 years, but in 2002, she began suffering from sick sinus syndrome and a permanent pacemaker was implanted, having a sequential pacing mode with right atrial and ventricular leads.

On May 23, 2002, she was admitted to Nakama Municipal Hospital because of high fever and abscess formation at the venous puncture site of the arteriovenous shunt. As Methicillin Resistant Staphylococcus Aureus (MRSA) was detected in the blood culture examination, she was treated with $0.5 \mathrm{~g}$ /day vancomycin $\mathrm{HCl}$ transvenous infusion immediately after hemodialysis for 3 days a week and then with $0.25 \mathrm{~g} /$ day for 2 weeks. She was also prescribed $200 \mathrm{mg} /$ day of minocycline $\mathrm{HCl}$ for 10 days. Vancomycin, which has an effective concentration at $25-40 \mu \mathrm{g} / \mathrm{ml}$ peak and $5-10 \mu \mathrm{g} / \mathrm{ml}$ trough points, was maintained at a plasma concentration (trough) of $10.4 \mu \mathrm{g} / \mathrm{ml}$ on May 31 and of $7.6 \mu \mathrm{g} / \mathrm{ml}$ on June 26 . At the end of June she began to complain of leg pain and lumbago. However, no lesion was detected in the abdominal and pelvic organs by computed tomograpghy (CT). On June 30, she was taken off antibiotics, because her blood culture had been negative twice and purulent exudate, redness and pain at abscess site had disappeared. Echocardiography detected no signs of infective endocarditis despite a persistent low-grade fever and positive c-reactive protein (CRP, about $3 \mathrm{mg} / \mathrm{dl}$ ). In mid July, her fever reached as high as $38^{\circ} \mathrm{C}$ despite the healed abscess at the puncture site. On July 25,3 weeks after the previous study, echocardiography detected a 
Table 1. Data on admission

\begin{tabular}{llllll}
\hline CBC & \multicolumn{5}{c}{ Blood chemistry } \\
WBC & $8800 / \mu \mathrm{l}$ & $\mathrm{TP}$ & $6.4 \mathrm{~g} / \mathrm{dl}$ & $\mathrm{Ca}$ & $9.4 \mathrm{mg} / \mathrm{dl}$ \\
Neutro & $92 \%$ & $\mathrm{Alb}$ & $2.7 \mathrm{~g} / \mathrm{dl}$ & $\mathrm{IP}$ & $3.2 \mathrm{mg} / \mathrm{dl}$ \\
Lympho & $3 \%$ & $\mathrm{~T}-\mathrm{bil}$ & $1.5 \mathrm{mg} / \mathrm{dl}$ & $\mathrm{UA}$ & $7.3 \mathrm{mg} / \mathrm{dl}$ \\
$\mathrm{Mono}$ & $5 \%$ & $\mathrm{D}-\mathrm{bil}$ & $0.9 \mathrm{mg} / \mathrm{dl}$ & $\mathrm{T}$-cho & $167 \mathrm{mg} / \mathrm{dl}$ \\
$\mathrm{RBC}$ & $229 \times 10^{4} / \mu \mathrm{l}$ & $\mathrm{AST}$ & $23 \mathrm{IU} / \ell$ & $\mathrm{TG}$ & $217 \mathrm{mg} / \mathrm{dl}$ \\
$\mathrm{Hb}$ & $7.3 \mathrm{~g} / \mathrm{dl}$ & $\mathrm{ALT}$ & $11 \mathrm{IU} / \ell$ & $\mathrm{TTT}$ & $8.4 \mathrm{KU}$ \\
$\mathrm{Ht}$ & $21.7 \%$ & $\mathrm{LDH}$ & $247 \mathrm{IU} / \ell$ & $\mathrm{ZTT}$ & $10.9 \mathrm{KU}$ \\
$\mathrm{Plt}$ & $4.2 \times 10^{4} / \mu \mathrm{l}$ & $\mathrm{ALP}$ & $709 \mathrm{IU} / \ell$ & $\mathrm{Amy}$ & $100 \mathrm{IU} / \ell$ \\
& & $\gamma-\mathrm{GTP}$ & $101 \mathrm{IU} / \ell$ & $\mathrm{CK}$ & $16 \mathrm{IU} / \ell$ \\
$\mathrm{Arterial} \mathrm{blood} \mathrm{gas}(\mathrm{room} \mathrm{air})$ & $\mathrm{BUN}$ & $54 \mathrm{mg} / \mathrm{dl}$ & $\mathrm{CRP}-\mathrm{Q}$ & $12.9 \mathrm{mg} / \mathrm{dl}$ \\
$\mathrm{pH}$ & 7.478 & $\mathrm{Cre}$ & $5.4 \mathrm{mg} / \mathrm{dl}$ & & \\
$\mathrm{PCO}_{2}$ & $32.3 \mathrm{mmHg}$ & $\mathrm{Na}$ & $137 \mathrm{mEq} / \ell$ & & \\
$\mathrm{PO}_{2}$ & $47 \mathrm{mmHg}$ & $\mathrm{K}$ & $3.7 \mathrm{mEq} / \ell$ & & \\
$\mathrm{BE}$ & $1.9 \mathrm{mEq}$ & $\mathrm{Cl}$ & $96 \mathrm{mEq} / \ell$ & & \\
$\mathrm{HCO}_{3}$ & $24.1 \mathrm{mmHg}$ & & & & \\
$\mathrm{SaO}_{2}$ & $85.8 \%$ & & & & \\
\hline
\end{tabular}

vegetation-like shadow $(11 \times 17 \mathrm{~mm})$ at the tricuspid valve. The patient was admitted to our hospital (on July 26) for further examination and therapy targeting the endocarditis.

Upon examination at admission, symptoms of inflammation were recognized, i.e. high body temperature, high $\mathrm{WBC}(8,800 / \mu \mathrm{l})$ and $\mathrm{CRP}(12.9 \mathrm{mg} / \mathrm{dl})$. Thrombo-cytopenia was recognized on admission(Table 1), followed by the persistent low level of platelet count $(40,000-80,000 / \mu 1)$ during hospitalization. Arterial blood gas analysis revealed hypoxemia, namely, arterial partial pressure of oxygen $\left(\mathrm{PaO}_{2}\right)$ and carbon dioxide $\left(\mathrm{PaCO}_{2}\right)$ measurements of $47 \mathrm{mmHg}$ and $32 \mathrm{mmHg}$, respectively (Table 1). A 12-lead electrocardiogram indicated a DDD pacemaker rhythm $(88$ beats $/ \mathrm{min})$. On bacterial examination, MRSA was identified in blood cultures at 4 different times. Transthoracic echocardiography revealed a $32.1 \times 10.4 \mathrm{~mm}$ vegetation attached to the ventricular side of the septal and anterior cuspids of the tricuspid valve. The body was shifted into the right atrium during the systolic phase from the right ventricle at the diastolic phase(Fig. 1). Due to the vegetation and destruction of the tricuspid valve, $\mathrm{III}^{\circ}$ regurgitant flow was detected across the valve at the pressure gradient of $88 \mathrm{mmHg}$, which indicated extreme high pulmonary pressure. Therefore, we diagnosed tricuspid valve endocarditis derived from MRSA sepsis, perhaps with septic pulmonary embolism.

Chest X-rays revealed a cardiothoracic ratio of $60 \%$, and enlarged central pulmonary arteries and a $\phi 15 \mathrm{~mm}$ nodular opacity were found in the right middle lung field (Fig. 2). The nodule with the inside cavity and pleural effusion was also confirmed by CT(Fig. 3). Perfusion lung scintigraphy showed decreased perfusion in the lateral portions of both lung lobes 


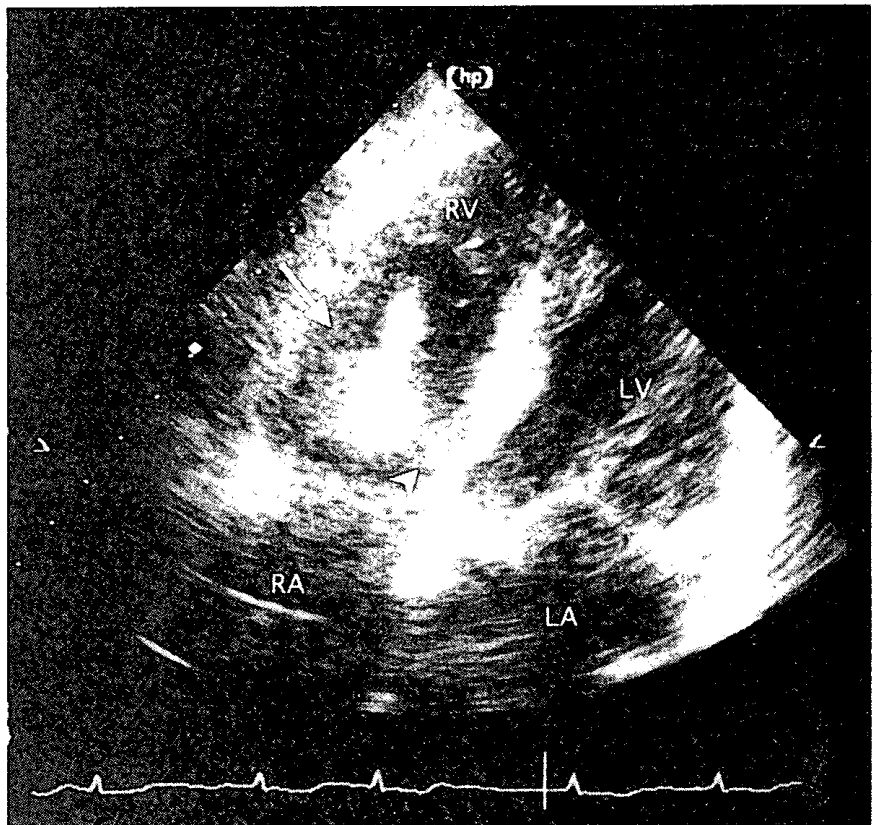

Fig. 1. Transthoracic echocardiography(apical four chamber view) shows the large vegetation (arrow) at the tricuspid valve, which is attached mainly to the septal cuspid (arrow head) and partially to the anterior cuspid.

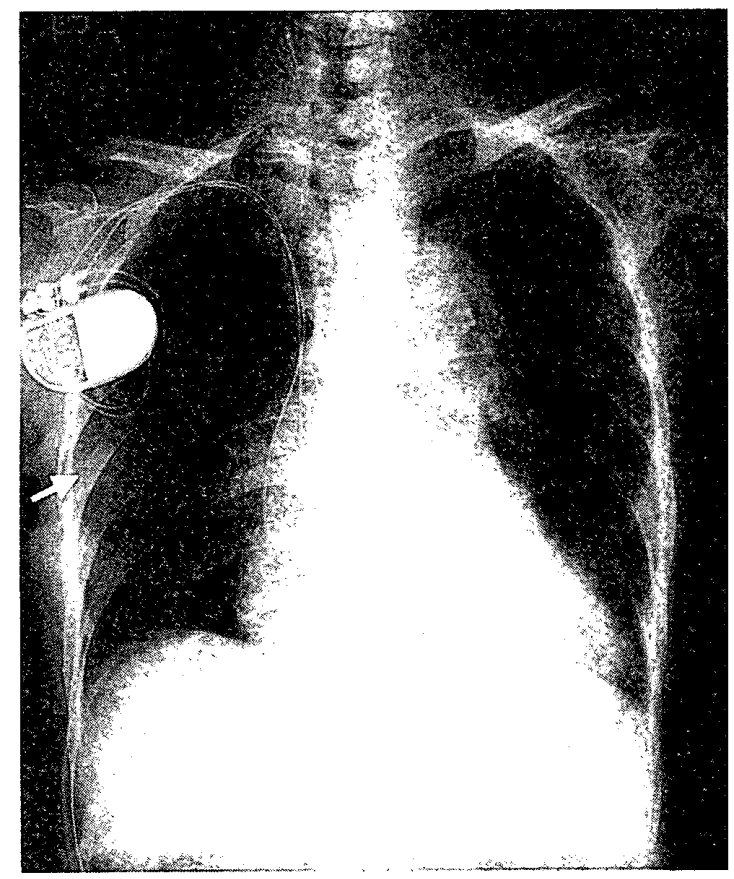

Fig. 2. Chest X-ray indicates cardiomegaly and a small nodule in the middle of the right lung field (arrow). 


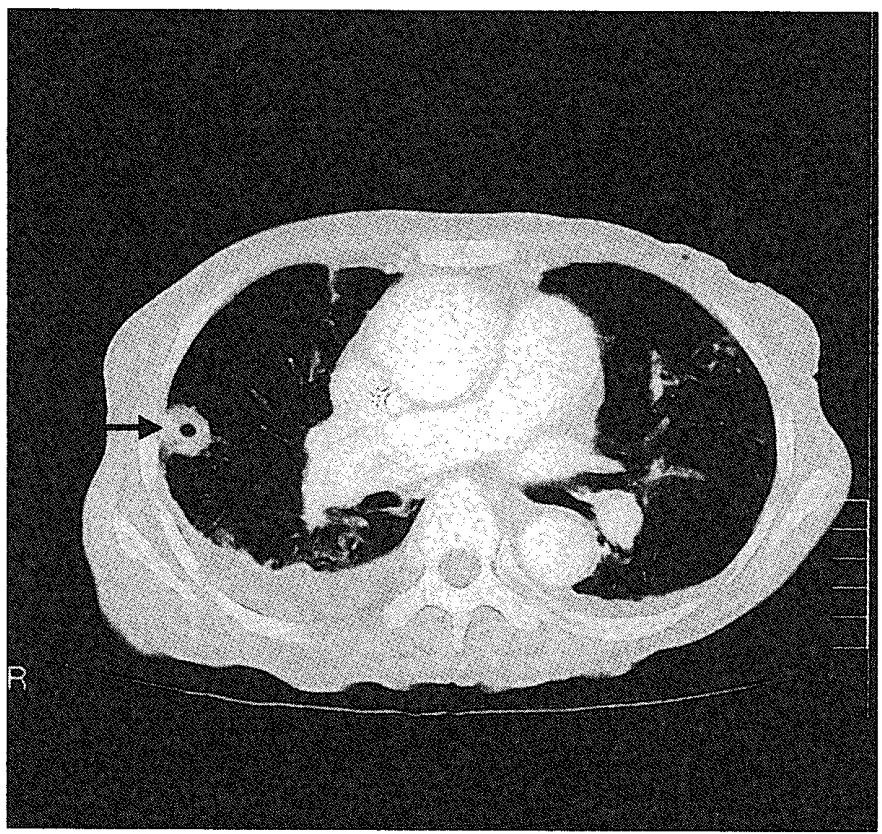

Fig. 3. Chest CT shows a nodule formation with an inside cyst (arrow), which is compatible with septic emboli and abscess formation.

\section{Anterior}

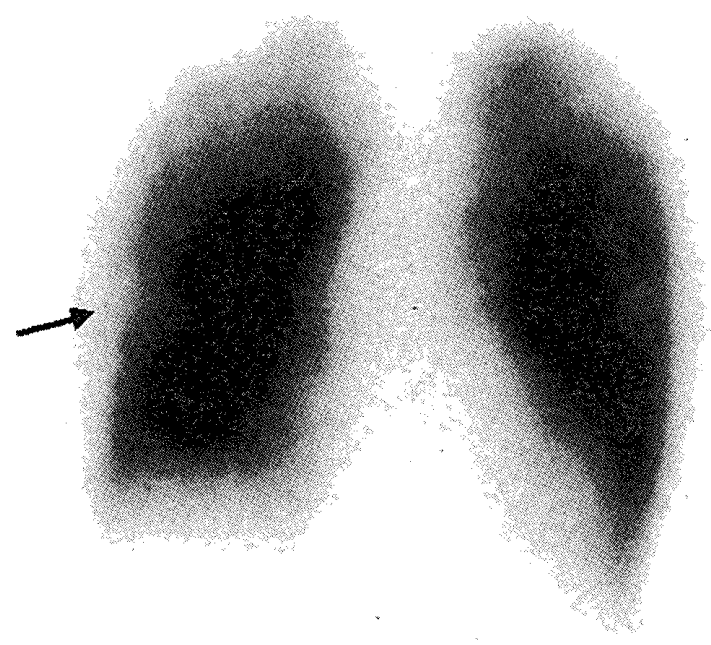

Fig. 4. Perfusion lung scintigraphy reveals reduced blood flow in the bilateral lung fields and the low uptake area(arrow), the same as the chest X-ray and CT. 


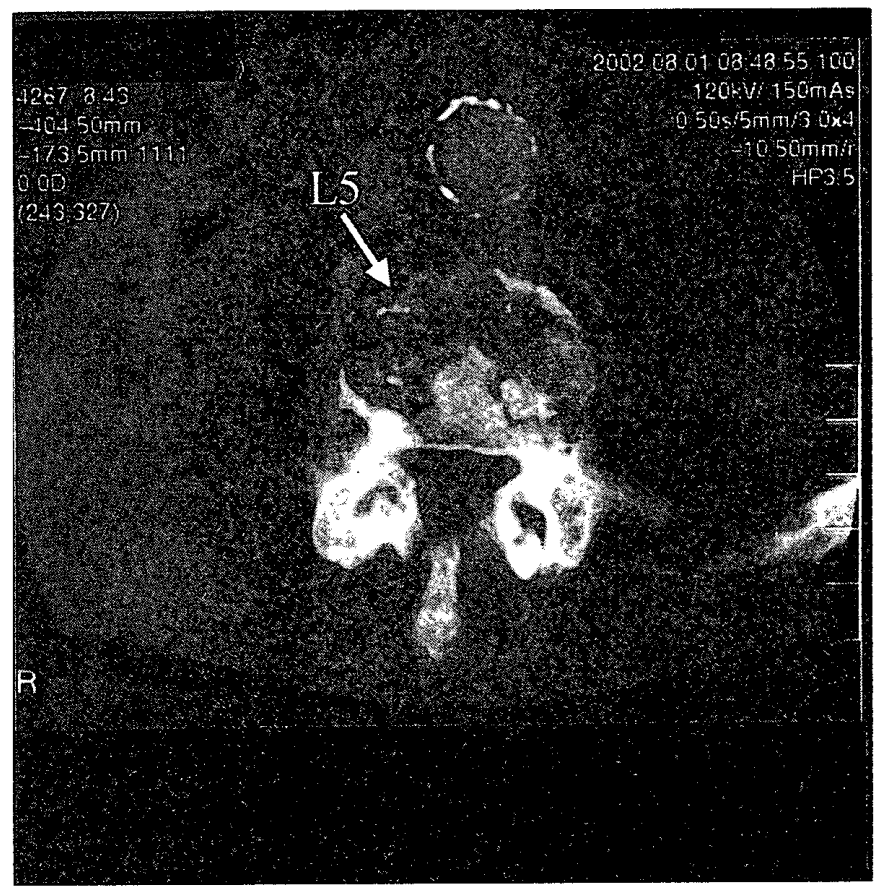

Fig. 5. Spine CT at L4 and L5 levels shows multiple low cysts and destruction of spine bodies.

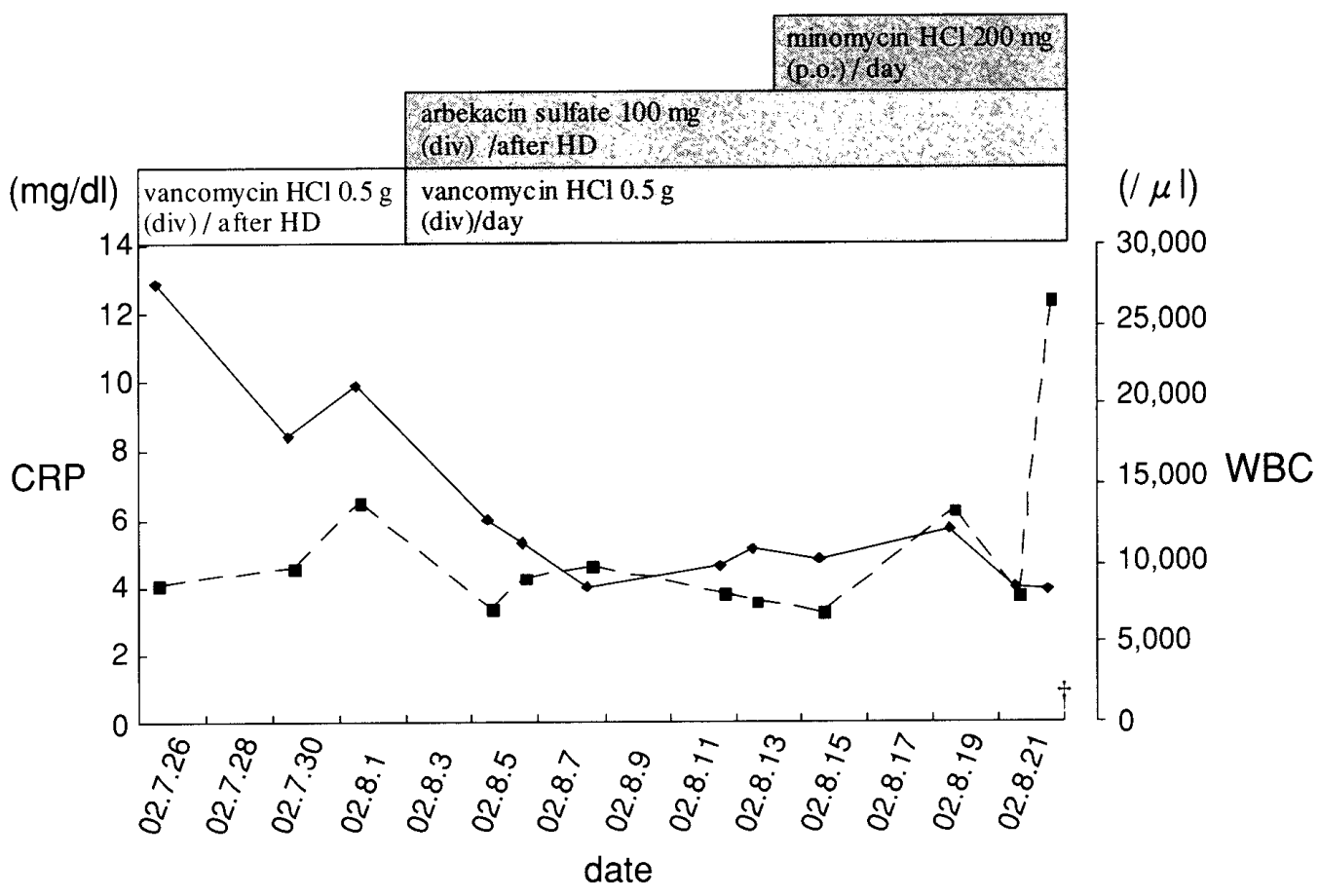

Fig. 6. Clinical course after admission to our hospital shows the usage of antibiotics and the change of CRP and WBC count.

$\rightarrow$ : CRP, $--\square--$ : WBC. 
(Fig. 4). On the other hand, the lung ventilation scan was normal. These findings were compatible with septic pulmonary embolisms. Additionally, X-rays showed osteolysis and narrow disk space of the L2/L3. CT revealed multiple $\phi 1 \mathrm{~mm}$ cystic spaces with bone destruction on the L4/L5 and L5/S1 margin area, which was compatible with pyogenic spondylitis (Fig. 5).

Although vancomycin was restarted immediately after admission to our hospital and had been administrated at the dose of $0.5 \mathrm{~g} / \mathrm{day}$, four times/week, a remarkable change was recognized in the level of CRP but not in WBC count. However, the biochemical examination on August 1 indicated prolonged prothrombin time, 14 seconds (control; 10.9 seconds), decreased serum fibrinogen $169 \mathrm{mg} / \mathrm{dl}$, increased serum fibrin destructive product (FDP) 2,896 $\mu \mathrm{g} / \mathrm{ml}$ and decreased antithrombin III 49\%. Therefore, we made a diagnosis of infectioninduced disseminating intravascular coagulation(DIC). We began treating with human antithrombin III (1,500 unit/day), heparin (18,000 unit/day) and gabexate mesilate $(1,200 \mathrm{mg} /$ day). Since the level of WBC and CRP did not decrease within normal range, we also added $100 \mathrm{mg}$ /day intravenous arbekacin sulfate and $200 \mathrm{mg}$ /day orally-administrated minocycline to vancomycin (Fig. 6). However, we could not control the infection and DIC, and the patient suffered from gastric bleeding on August 22 and died from shock on August 23.

\section{Discussion}

The infectious focuses in infective endocarditis are found in the left side of the heart in about $70 \%$ of all cases, $41-42 \%$ of which are at the mitral valve and $31.5-33 \%$ at the aortic valve. In contrast, infective endocarditis in the right side of the heart is rare, only $5-10$ $\%$ of all cases. Moreover, right-sided endocarditis mainly occurs at the tricuspid valve rather than at the pulmonary valve $[4-6]$. In European countries and the United States, infective endocarditis in the right side of the heart has been frequently reported in drug abusers. However, in Japan where drug abuse is rare, right-sided endocarditis rarely occurs in patients with congenital heart disease such as ventricular septal defects or long-term intravascular catheter users [1]. In cases where bacteria are the cause of right-sided heart endocarditis, Staphylococcus aureus is the most common cause, up to $80 \%$ of all cases. Furthermore, MRSA has recently increased in frequency among staphylococcal species. The other $20 \%$ of right-sided heart endocarditis cases are caused by streptococcal species, fungus (Candida albicans) or gram-negative rod bacteria [4-6].

Infective endocarditis in patients undergoing regular hemodialysis occurs 21 to 54 times more frequently than in the normal population [7]. Pacemaker implantation alone has been classified as a negligible-risk category for infective endocarditis by the American Heart Association $[8,9]$. Artificial vessels and temporary catheters are common means of blood access in hemodialysis patients with endocarditis, while endogenous arteriovenous fistula is rarely used for access in endocarditis [10]. Moreover, although dialysis patients have more 
chances to be exposed to bacteremia, the frequency of right-sided endocarditis (only $5 \%$ of all endocarditis) is similar to that found in non-dialysis patients. The reason is likely due to the characteristics of the right side of the heart that underlie heart disease such as the lower frequency of rheumatic valve disease, less endothelial damage due to low circulation pressure, and the fact that bacterial growth slows under low oxygen conditions [4]. All these characteristics are identical in dialysis patients and non-dialysis patients.

The features of right-sided endocarditis are respiratory complications with septic pulmonary embolism, which is induced by bacterial emboli from infectious phlebitis or endocarditis lesions. Septic pulmonary emboli are diagnosed by the hallmark of chest CT, that is cavity formation by necrosis [11]. In our case, it was comfirmed by chest X-ray and CT. Pyogenic spondylitis is attributed to bacteremia, of which etiologies of infective endocarditis are the most common $(43 \%)$. Recently, cases in long-term hemodialysis patients, referred to as hemodialysis spondylitis increased, perhaps due to frequent incidences of bacterial exposure and decreased immuno-protective function. In our case, both factors, long-term hemodialysis and endocarditis, easily gave rise to pyogenic spondylitis.

Since right-sided endocarditis responds well to internal medical therapies, namely antibiotics and cardiovascular drugs, we can usually achieve a better prognosis in right-sided endocarditis than in left-sided endocarditis. However, we also have some factors for poor prognosi; 1) persistent bacteremia after 5 days antibiotics, 2) relapse after cessation of antibiotics, $3)$ destruction of myocardium, 4) recurrent embolism even with antibiotics therapy, 5) more than $10 \mathrm{~mm}$ vegetation and 6) occurrence of congestive heart failure or atrial ventricular block.

Additionally, infection by staphylococcus, gram-negative bacilli or fungus tends to be a fast-developing and refractory endocarditis [4]. The present case was matched to the facts of relapse after cessation of antibiotics, more than $10 \mathrm{~mm}$ vegetation, and infection by staphylococcus. Therefore, as we could not control endocarditis in the present case, DIC resulted.

Furthermore, our case also had other problems such as poor nutrition(Alb $2.4-2.7 \mathrm{mg}$ / $\mathrm{dl}$ ), and poor control of pyogenic spondylitis, guessed at by the persistent pain. Although we could not elucidate the etiology of the thrombocytopenia, we speculated that it aggravated the DIC state. A major limitation in our discussion of the patient is that we could not obtain permission to perform a transesophageal echocardiography and an autopsy and consequently we are unable to provide details of the vegetation and pulmonary embolism.

We have reported on a patient with infective tricuspid valve endocarditis and discussed the etiology of long-term hemodialysis, pacemaker implantation and pyogenic spondylitis. Hereafter, patients with diabetes mellitus, and by bacterial infections, will increasingly be introduced to hemodialysis therapy. We believe this case report will be informative for treating infective endocarditis in increasingly compromised hemodialysis patients. 


\section{References}

1. McCarthy JT \& Steckelberg JM(2000): Infective endocarditis in patients receiving long-term hemodialysis. Mayo Clin Proc 75: 1008-1014

2. Hecht SR \& Berger M(1992): Right-sided endocarditis in intravenous drug users. Annals of Internal Medicine 117: $560-566$

3. Weisse AB, Heller DR, Schimenti RJ, Montgomery RL \& Kapila R(1993): The febrile parenteral drug user: a prospective study in 121 patients. Am J Medicine 94: 274-280

4. Robbins MJ, Soeiro R, Frishman WH et al (1986): Right-sided valvular endocarditis. Etiology, diagnosis and an approach to therapy. Am Heart J 111: 128-135

5. Tornos MP, Permanyer-Miralda G, Olona M, Gil M, Galve E, Almirante B \& Soler-Soler J(1992): Long-term complications of native valve infective endocarditis in non-addicts. Annals of Internal Medicine 117: $567-572$

6. Fernandez-Cean J, Alvarez A, Burguez S, Baldovinos G, Larre-Borges P \& Cha M(2002): Infective endocarditis in chronic haemodialysis: two treatment strategies. Nephrol Dial Transplant 17: $2226-2230$

7. Brueck M, Rauber K, Wizemann V \& Kramer W(2003): Infective tricuspid valve endocarditis with septic pulmonary emboli due to puncture of an endogenous arteriovenous fistula in a chronic hemodialysis patient. J Infect 46: $188-191$

8. Nakatani S, Mitsutake K, Hozumi T et al (2003): Current characteristics of infective endocarditis in Japan. - An analysis of 848 cases in 2000-2001-. Circ J 67: 901-905

9. Duval $X(2004)$ : Pacemaker-related infective endocarditis affects 550 cases per million recipients. Clin Infect Dis 39: 68-74

10. Maraj S, Jacobs LE, Kung SC, Raja R, Krishnasamy P, Maraj R, Braitman B \& Kotler MN(2002): Epidemiology and outcome of infective endocarditis in hemodialysis patients. Am J Med Sci 324: $254-260$

11. Kuhlman JE, Fishman EK \& Teigen C(1990): Pulmonary septic emboli: diagnosis with CT. Radiology 174: $211-213$ 
慢性透析患者の内シャント穿刺部膿場により生じた三尖弁感染性心内膜炎

平川乃理子'，太崎 博美'，田中 正哉1，山下 和仁'，岡崎 昌博1, 中島 康秀, 椛島 成利 ${ }^{2}$, 田村 雅仁

'産業医科大学 医学部 第二内科学教室

産業医科大学病院 腎センター

要 旨： 維持透析患者は人工血管などのアクセスにより心内膜炎の高い危険性があるが, 右心 系心内膜炎は何らかの素因なく発生することは稀である.症例は72歳女性,慢性腎不 全維持透析中で,ペースメーカー植え込み術を施行されていた。透析用内シャント付 近に膿瘍形成後, 発熱, 腰痛を主訴に入院した。血液培養にて MRSA 同定, 心臓エコー による三尖弁に付着した疮賛の描出,および胸写,肺血流シンチにて遊離塞栓による と推測される肺塞栓を認めた。CTにより,L4, L5に化膿性脊椎炎を認めた. 維持透析患 者に扔いて繰り返される血管の穿刺が内シャントといえども細菌にさらされ,感染性 心内膜炎の高い危険となると考え報告した。

キーワード：感染性心内膜炎，三尖弁，透析，恒久的ペースメーカー．

J UOEH(産業医大誌) 26 (4): 451-460（2004） 